\title{
FRIENDSHIP AND CONTEMPLATION \\ IN THE CARTA PARA ARIAS MONTANO
}

\author{
Terence O'Reilly \\ University College Cork
}

7 The blending of Spanish and Italian traditions that characterises the poetry of Francisco de Aldana is evident in his verse epistle to Arias Montano, ${ }^{1}$ which is shaped in two ways by the doctrines of Florentine neoplatonism: first, in its teaching that contemplation involves an ascent from the beauty of this world to that of its Creator, and second, in its celebration of male friendship as the context in which contemplation is attained. ${ }^{2}$ This study will trace in the poem the development of these two themes, and it will show how their connection throws light on one of its most enigmatic features: the parallels and repetitions that determine its form.

Part One: Arias (ll. 1-279)

Scholars have described in differing ways the divisions into which the poem falls, and no consensus exists about its structure. ${ }^{3}$ They agree, however, that it begins with a play on Montano's first surname, Arias:

Montano, cuyo nombre es la primera estrellada señal por do camina

el sol el cerco oblicuo de la esfera,

nombrado así por voluntad divina, para mostrar que en ti comienza Apolo la luz de su celeste diciplina (11. 1-6)

Montano is compared to the constellation of Aries, which the sun (an image of the divinity itself) enters in springtime, at the start of the year, and he is said to be the mediator of Apolo's heavenly teaching. This allusion to Montano's wisdom as a teacher explains the three sections of the first Part that follow, in which Aldana outlines the stages of the contemplative way as he understands it. Here, as recent research has shown, there are a number of references to Montano's own writings on the subject. ${ }^{4}$ 
In the opening section (11. 7-66), Aldana describes his experience of the first stage in the process: conversion of heart. Looking back on his life, he sees he has been tormented by two forms of moral disorder: the desire for military glory, and sensual love. ${ }^{5}$ But now, at last, he has overcome them, and he is free to embark on a spiritual quest. To convey the struggle this has involved, he introduces the image of a goblin (un trasgo), whom he has fought in hand-to-hand combat:

y con un trasgo a brazos debatiendo

que al cabo, al cabo, jay Dios!, de tan gran rato

mi costoso sudor queda rïendo. (1l. 41-43)

The next section (11. 67-123) outlines the remaining stages of the contemplative journey that lies before him, and two comparisons are used to make the point, dear to neoplatonism, that it involves ascending from created things to the Creator: first, the image of a still, in which the scent of a rose is extracted to make perfume (11. 70-75); and second, that of Jacob's ladder, rising from earth to Heaven (11.109-17). Then, in the final section (11. 124-279), the poet appears to go over the same material again, in more detail. This repetition was interpreted by Robert Archer as a sign of Aldana's confusion: his difficulty in articulating a teaching beyond his grasp. ${ }^{6}$ But Aldana himself explains it in other terms: having outlined the process in general, he wishes now to focus on certain practical steps a soul can take to reach the goal:

quiero, para tejer tan rica tela, muy desde atrás decir lo que podría

hacer el alma que a su causa vuela. (11. 127-29)

This he does in what follows. First, he describes the kind of place in which prayer is best practised:

Paréceme, Montano, que debría

buscar lugar que al dulce pensamiento, encaminando a Dios, abra la vía (1l. 130-33)

Then he suggests as a subject for meditation the creation of the self by God out of nothing, and he notes, in particular, the divine goodness displayed in the creation of the smallest beings:

Enamórese el alma en ver cuán bueno

es Dios, que un gusanillo le podría

llamar su crïador de lleno en lleno (1l. 169-71) 
Finally, he gives advice about how to make the tricky transition from meditation to contemplation, a subject that San Juan de la Cruz was to write about a few years later, ${ }^{7}$ and he sums up his advice in the beautiful image of Rebecca preparing to meet Isaac (11. 247-58). The first part ends with the poet attempting, without success, to put into words the spiritual riches that contemplation conveys. His failure illustrates a claim often made in mystical writings, and that he himself resumes succinctly: "que en tal lugar la lengua más despierta /es de natura error y balbucencia" [11. 185-86).

Part Two: Montano (ll. 280-351)

At line 280, the poem moves on from the subject of Montano's wisdom as a teacher to consider another aspect of his character: his moral integrity. The primary image shifts too: instead of the sun, we are presented with the image of a mountain, an ancient symbol of contemplative experience ${ }^{8}$, and the pun on the name Arias is replaced by play on the addressee's second surname, Montano. The mountain described in detail here rises high above the clouds towards the sun, and a shepherd is pictured on its summit, looking down in safety on the storms beneath. The image is then applied to Montano, whose virtues raise Aldana above the conflicts engendered by the deadly sins, setting him free to admire Montano's holiness:

Pareces tú, Montano, a la gran cumbre deste gran monte, pues vivir contigo es muerte de la misma pesadumbre,

es un poner debajo a su enemigo (...)

y desta turba vil que el mundo envicia descargado, gozar cuanto ilustrare

el sol en ti de gloria y de justicia. (11. 319-22, 331-33)

In this part of the poem there are a number of parallels and contrasts with what comes earlier, and it acquires its full meaning only when these are taken into account. The parallels are mainly with the initial stanzas and the opening section of Part One (1l. 1-66). Both parts begin by applying the sun-image to the divine mysteries. In Part Two, Aldana compares his presumption in speaking of them to that of Daedelus:

¿Notaste bien, dotísimo Montano, notaste cuál salí, más atrevido que del cretense padre el hijo insano? [11. 283-85) 
Both parts acknowledge also Montano's pre-eminence as a teacher. In Part Two he is said to be a prophetic voice on Mount Sion that the Muses leave Mount Pindus to hear (11. 286-94), a reference, it would seem, to Montano's writings, in which classical and biblical traditions were combined. Then Aldana expresses his desire to live with Montano:

¡Oh tres y cuatro veces yo dichoso si fuese Aldino aquél, si aquél yo fuese que, en orden de vivir tan venturoso,

juntamente contigo estar pudiese, lejos de error, de engaño y sobresalto, como si el mundo en sí no me incluyese! (1l. 298-303)

His words recall the ambition, voiced in Part One, to die to the world in a solitary retreat:

Y porque vano error más no me asombre, en algún alto y solitario nido pienso enterrar mi ser, mi vida y nombre (1l. 52-54)

Now, however, he affirms that it is with and through Montano that this longing will be fulfilled. Part Two ends by recalling and developing the image of the trasgo whom Aldana was said in Part One to have been fighting. Now the poet compares his soul resisting temptation to Hercules battling to master Antaeus, and he indicates that it will succeed by drawing on Montano's moral strength:

El alma que contigo se juntare cierto reprimirá cualquier deseo que contra el proprio bien la vida encare;

podrá luchar con el terrestre Anteo de su rebelde cuerpo, aunque le cueste vencer la lid por fuerza y por rodeo,

y casi vuelta un Hércules celeste, sompesará de tierra ese imperfeto, porque el favor no pase della en éste,

tanto que el pie del sensitivo afeto no la llegue a tocar y el enemigo al hercúleo valor quede sujeto (11. 334-45)

These parallels underline that the conversion of heart that the spiritual journey demands, a conversion that so far Aldana has struggled 
alone to achieve, will become fully attainable once he can be with his friend.

\section{Part Three: Nuestra soledad contemplativa (1l. 351-451]}

The subject of the last part of the poem is the contemplative solitude that Aldana hopes he and Montano will one day share. To convey it, he describes a marine landscape which some critics have taken to be a real place: probably Monte Urgull, the site of the fortress of San Sebastián where Aldana was posted in $1576 .{ }^{9}$ However, if the topography he describes is read with the earlier parts of the poem in mind, it acquires an interior and symbolic sense as well. The parallels here are mainly with the second and third sections of Part One.

Aldana begins by defining the type of location that would be appropriate for their retreat:

Mas para conclüir tan largo tema, quiero el lugar pintar do, con Montano, deseo llegar de vida al hora extrema (1l. 352-54)

His words recall the start of Part One, section 3, where he emphasised the importance to the soul of choosing somewhere apt for contemplation. The place he envisages now, which lies between the extremes of mountain and valley, is fruitful all the year round, and filled with spring flowers:

las partes medias son más aprobadas

de la natura, siempre frutüosas,

siempre de nuevas flores esmaltadas. (11. 361-63)

In Part One the rains of Spring and the wild flowers they raise up were firmly associated with contemplation:

pues la impotencia misma que la tierra

tiene para obligar que le dé el cielo

llovida ambrosia en valle, en llano, o en sierra,

o para producir flores el hielo

y plantas levantar de verde cima

desierto estéril y arenoso suelo,

tiene el alma mejor, de más estima, para obligar que en ella gracia influya el bien que a tanta alteza le sublima. (11. 187-207) 
No tiene que buscar los resplandores

del sol quien de su luz anda cercado,

ni el rico abril pedir hierbas y flores (11. 220-22)

Similarly, in Part Two the fertility and temperate clime of Spring were features of the symbolic mountain:

Todo es tranquilidad de fértil mayo,

purísima del sol templada lumbre,

de hielo o de calor sin triste ensayo. (11. 316-18)

Aldana next describes their retreat as a 'nest':

Quiero también, Montano, entre otras cosas, no lejos descubrir de nuestro nido el alto mar, con ondas bulliciosas (11. 364-66)

The metaphor was used earlier, in Part One, of the poet's ambitions: "en algún alto y solitario nido / pienso enterrar mi ser, mi vida y nombre" (11. 53-54). Then he saw himself alone; now, however, the hiding place he seeks will be shared. From their nest the friends will enjoy a splendid view:

dos elementos ver, uno movido del aéreo desdén, otro fijado, sobre su mismo peso establecido;

ver uno desigual, otro igualado, de mil colores éste, aquél mostrando

el claro azul del cielo no añublado. (1l. 367-72)

He mentions two elements (dos elementos), the sea and the land, but in fact a third will be present too: the clear blue sky reflected in the sea. All three were associated earlier with contemplation. The image of the land we have studied already; here the poet alludes, once again, to Spring flowers (de mil colores éste). The sun, associated with the divine from the start, becomes in Part One an image of God's presence, with which the contemplative soul is united:

(...) como el aire, en quien en luz se extiende el claro sol, que juntos aire y lumbre ser una misma cosa el ojo entiende. (11. 106-08)

Puede del sol pequeña fuerza ardiente desde la tierra alzar graves vapores a la región del aire allá eminente, 
¿y tantos celestiales protectores, para subir a Dios alma sencilla, vernán a ejercitar fuerzas menores? (11. 118-23)

y poco a poco le amanezca el día de la contemplación, siempre cobrando luz y calor que Dios de allá le envía. (11. 172-74; cf. 11. 188-95)

At the end of the inner journey, the soul is clothed in light entirely:

recogida su luz toda en un punto, aquella mirará de quien es ella indinamente imagen y trasunto

$\mathrm{y}$, cual de amor la matutina estrella dentro el abismo del eterno día, se cubrirá toda luciente y bella. (1l. 241-46; cf. 11. 283-85)

The most prominent image of contemplation in Part One, however, is the sea. ${ }^{10}$ The soul is pictured as immersed in the deep ocean of God himself, yet not destroyed:

No que del alma la especial natura, dentro al divino piélago hundida, cese en el hacedor de ser hechura,

o quede aniquilada y destrüida, cual gota de licor, que el rostro enciende, del altísimo mar toda absorbida (1l. 100-05; cf. 11. 148-50, 238-40)

And the poet acknowledges, at the end of Part One, that to talk of divine realities is to risk drowning:

Mas jay de mí!, que voy hacia el profundo do no se entiende suelo ni ribera, y si no vuelvo atrás, me anego y hundo. (11. 277-79)

In the final lines, Aldana imagines himself and Montano going down to the shore where land and sea meet. There, united in love, they will talk of marvels (maravillas) that they have pondered deeply:

Bajaremos allá de cuando en cuando, altas y ponderadas maravillas en recíproco amor juntos tratando. (11. 373-75) 
The first marvel mentioned is thousands of shells lying on the sand and the tiny creatures that inhabit them. The description of the scene, which spreads over eleven stanzas, has been linked with Montano's enthusiasm for collecting shells, which was well known. ${ }^{11}$ But allusions within it to earlier parts of the poem suggest other overtones too. The shells are washed by the sea and struck by sunlight, two of the natural features associated with contemplation, as we have seen. Furthermore, they reflect the sun's rays, becoming themselves, as it were, sources of light:

echan como de sí nuevos resoles

do el rayo visüal su curso enfrena. (1l. 381-82)

despidiendo de sí como centellas, en rica mezcla de oro y de turquesa. (11. 388-89)

The images call to mind the Naturae historia of Montano, where, as José Lara Garrido has noted, the shells of the sea are said to proclaim their Maker's glory. ${ }^{12}$ The creatures within the shells are then evoked in lines that recall the meditation proposed earlier, in Part One, where God's goodness was discerned in the most vulnerable forms of life. Aldana refers to them as hidden, carefully crafted 'fish' (11. 391-96), and to the shells that enclose them as 'thick bodies' and 'rock-like walls', from which they come and go (11. 400-05). His words remind us of earlier lines on the roles of the soul and the body in contemplation. In Part One the soul was described as a fish, immersed in the ocean of God:

pues no mejor el húmido pescado

dentro el abismo está del oceano, cubierto del humor grave y salado,

que el alma, alzada sobre el curso humano, queda, sin ser curiosa o diligente, de aquel gran mar cubierta ultramundano (11. 223-28)

Contemplation itself was depicted as a fish, coming and going to God:

cual pece dentro el vaso alto, estupendo,

del oceano irá su pensamiento

desde Dios para Dios yendo y viniendo. (11. 85-87)

And the contemplative's body was seen first as a cave and then as a rock, covered by the divine sea: 
Y ¿qué debiera ser, bien contemplando, el alma sino un eco resonante a la eterna beldad que está llamando

$\mathrm{y}$, desde el cavernoso y vacilante cuerpo, volver mis réplicas de amores al sobrecelestial Narciso amante (...)? (11. 58-63)

Ojos, oídos, pies, manos y boca, hablando, obrando, andando, oyendo y viendo, serán del mar de Dios cubierta roca (1l. 82-84)

These earlier passages are brought to mind again by what follows immediately. The two friends, it is affirmed, will behold the interplay of sea and rock on the shore:

¡Ver los marinos riscos cavernosos por alto y bajo en varia forma abiertos, do encuentran mil embates espumosos (...)! (11. 409-11)

They will also watch the fish making their way, with trepidation, through the water:

los peces acudir por sus inciertos caminos con agalla purpurina, de escamoso cristal todos cubiertos (11. 412-14)

Then, raising their gaze, they will see a ship sailing fast towards distant lands:

También verás correr por la marina, con sus airosas tocas, sesga y presta, la nave, a lejos climas peregrina. (11. 415-17)

The image was used earlier, in Part One, of the poet's reflections on contemplation, which were compared to a ship crossing the sea of God in search of infinity:

(...) Montano, va mi navecilla corriendo este gran mar con suelta vela, hacia la infinidad buscando orilla (1l. 124-26)

It informed as well the later metaphor of God's Indies, which the contemplative is called to master, like a conquistador: 
¡Oh grandes, oh riquísimas conquistas de las Indias de Dios, de aquel gran mundo tan escondido a las mundanas vistas! (11. 274-76)

The last part of the poem, it may be held, does more than portray a place in the material world where Aldana and Montano will end their lives. It evokes, as well, the spiritual world of contemplation that they will discover and conquer. ${ }^{13}$ That this is so is confirmed by the final marvel described: the sea itself, which they will witness, it is said, in two contrasting moods: at times storm-tossed, a sight to inspire fear, at other moments deceptively calm. The image is an allegory of the contemplative life, as the poet's closing words denote:

En fin, Montano, el que temiendo espera

y velando ama, sólo éste prevale

en la estrecha, de Dios, cierta carrera. (11. 433-35)

\section{Conclusion}

The Carta para Arias Montano is, at first sight, a confusing poem, marked by parallels and repetitions that make its structure hard to discern. But when these features are studied in the light of its main themes, contemplation and friendship, it emerges as carefully organised to achieve its goal. A turning point occurs at the end of Part One: the material set out before then is taken up again in Parts Two and Three, and developed further. The teaching on contemplation that Part One presents is applied in what follows to the poet's friendship with Montano, which thereafter becomes not only the context of the contemplative life but the means by which it is attained. The considered nature of this design is made clear by the proportions inherent in the work. The point at which Part One ends, line 279, corresponds to the Golden Section, so prized in Renaissance aesthetics, and the ratios that result constitute an ideal equilibrium: Parts Two and Three stand to Part One as Part One itself stands to the poem as a whole. ${ }^{14}$

It is friendship that binds the various parts together. In the final lines, the poet refers to Montano as the best portion of himself: "(. . .) escribiendo / a ti, que eres de mí lo que más vale" (11. 437-38). And he describes himself, in turn, as a member, a part, of Montano: "que nunca de su todo se desmiembre /ésta tu parte y siempre serlo pueda" (1l. 446-47).

As friends, the two men indwell each other. This explains why, in Part One, Aldana feels able to rehearse a series of teachings on contemplation that Montano already knows: the knowledge to which he gives expression stems from that part of him in which Montano lives. It also explains why he can affirm, in Part Two, that in and 
through Montano he will rise to the moral rectitude he desires: Montano, living in him, gives him strength. Above all, it accounts for the content of Part Three. Because they indwell each other, the two friends are able to share not only the aspiration to contemplation but the experience of contemplation itself. Hence Aldana can refer, paradoxically, to their solitude as 'shared': nuestra soledad contemplativa (1. 440). This theme, which the Carta explores, is not characteristic of the Western monastic tradition, which generally sees the solitude that contemplation involves as private and individual. ${ }^{15}$ It makes sense, however, in the context of Florentine neoplatonism, and the classical teachings on friendship it developed, which were diffused in Spain by Leone Ebreo:

Los que están en verdadera amistad tienen doble vida, constituida en dos personas: en la suya y en la del amigo; de tal manera que su amigo es otro él mismo y que cualquiera de los dos abraza en sí dos vidas juntamente: la suya propia y la del amigo (...) Y la causa de la tal unón y vínculo es la recíproca virtud o la sabiduría de los dos amigos, la cual (...) engendra en los amigos una propia esencia mental, conservada con saber, con amor y voluntad común a los dos (...). Y a lo último te digo que la amistad honesta hace de una persona dos y de dos una. ${ }^{16}$

\section{Notes}

${ }^{1}$ Carta para Arias Montano sobre la contemplación de Dios y los requisitos della. The poem is dated 7 September 1577 (11. 450-51). References are to the edition by José Lara Garrido (437-58).

'On the 'doctrinal Neoplatonism' of the poem see Alexander Parker (1977: 81; 1985: 68-71).

${ }^{3}$ The analyses of the structure offered by Alfredo Lefebvre, Elias Rivers (1955) and Manuel Morales Borrero are found unconvincing by Robert Archer (23738 ), for whom the poem belongs to "a submerged genre of ostensibly formless poems" $(249$, n.31). His own analysis differs in turn from the interpretations of José Lara Garrido (98-106), D. Gareth Walters (127-40) and Antonio Prieto (277-83).

${ }^{4}$ See the detailed observations and references in Luis Gómez Canseco (15263). I am grateful to Dr Grace Magnier for drawing my attention to this study. ${ }^{5}$ Cf. Parker (1985: 68) who notes that the poem "opens with a reference to the poet's early years which he calls his lost life, a wasted youth spent in the pursuit of two follies [11. 10-21]. One of these must have been sensual love and the other the ambition for military and political advancement."

${ }^{6}$ Archer (241): "It is because he is aware that he has failed to give the impression that he has really grasped the complexity and difficulty of his spiritual undertaking, and has not shown that he is capable of keeping to even the rather vague path he has sketched, that Aldana addresses 
Montano again in lines 124-29 (...) He declares apologetically that he must start again at the beginning (muy desde atrás) if he is adequately to describe the spiritual ascent he envisages."

${ }^{7}$ Subida del Monte Carmelo 2:13, Noche oscura del alma 1: 9, Llama de amor viva 3: 32. References are to the edition of San Juan de la Cruz: obras completas (1993) by José Vicente Rodríguez and Federico Ruiz Salvador. The saint is thought to have composed these three works (including the second redaction of the Llama de amor viva) between 1578 and 1591; see Eulogio Pacho (876-80, 1018$20,1360-65)$. His teaching on the transition from meditation to contemplation is discussed by E.W. Trueman Dicken (145-69).

${ }^{8}$ The biblical associations of the mountain are traced by Léon-Dufour (32831 ), and the presence of the image in patristic exegesis is discussed by Cuthbert Butler (lxxvii-lxxix). See too William Johnston (290): “The towering figure of Moses the mystic, climbing the mountain and entering the cloud, is central to the whole apophatic tradition from Gregory of Nyssa and Dionysius to the author of The Cloud [of Unknowing] and St John of the Cross." The mountain symbol underlies a number of devotional and mystical works composed in sixteenth-century Spain, in addition to the Subida del Monte Carmelo of San Juan de la Cruz, among them Bernardino de Laredo, Subida del Monte Sión $(1535,1538)$ and San Alonso de Orozco, Monte de contemplación (1544).

${ }^{9}$ Rivers (1966: xxii, xxv). For Ruiz Silva (237-38) the locus amoenus evoked in the poem, "tiene una indudable realidad tangible (...). O mucho nos equivocamos o Aldana está describiendo a su amigo una vida futura - pero inmediata - en San Sebastián."

${ }^{10}$ On the history of the image see Bernard McGinn.

${ }^{11}$ See Lara Garrido 455.

${ }^{12}$ Lara Garrido 104-05.

${ }^{13}$ The possibility of a spiritual interpretation of the seascape was suggested by José Bergamín (162-63): "Maravillas del mar y el suelo cubren de su natural apariencia el empeño divino del contemplador, reflejándole a su Criador en ellas. Como imagen y figuración teatral, visible, de aquellas otras realidades a que llama el poeta, con certero tino, 'las Indias de Dios' (...). Mundo de reflejo, eco divino, de aquel otro, tan escondido al propio contemplar mundano." It was carried further by Lara Garrido, who cites Bergamín (104, n.4), and by Archer (245-46) and Walters (137-38).

${ }^{14}$ The New Shorter Oxford English Dictionary defines the Golden Section as, "(the proportion resulting from) the division of a straight line into two parts so that the ratio of the whole to the larger part is the same as that of the larger to the smaller part." The proportion in the poem may be represented schematically as follows:

$$
\mathrm{A} \quad \mathrm{M}=279 \quad \mathrm{~B}=451 \quad \mathrm{AB}: \mathrm{AM}=\mathrm{AM}: \mathrm{MB}
$$

${ }^{15}$ See O'Reilly and the entry under soledad in Dinzelbacher (930-32). There are exceptions, notably the contemplative experience that St Augustine shared with his mother Monica at Ostia, which he describes in The Confessions, Book 
9: 23-26. The notion of "contemplative friendship" is discussed in Johnston (290-93).

${ }^{16}$ Andrés Soria Olmedo (56-57). As Ebreo makes clear, the definition of friendship that he develops in this passage derives from Aristotle. Dian Fox finds in the friendship that the poem celebrates a powerful erotic element: the poem is "a sublimation of desire" (73), "fraught with sexual tension" (77). On the role of sexuality in "mystical friendship" see Johnston (149-59).

\section{Works Cited}

Archer, Robert. "The overreaching imagination: the structure and meaning of Aldana's Carta a Arias Montano." Bulletin of Hispanic Studies 65 (1988): 237-49.

Bergamín, José. Beltenebros y otros ensayos sobre literatura española. BarcelonaMadrid: Noguer, 1973.

Butler, Cuthbert. Western Mysticism. $2^{\text {nd }}$ ed. London: Constable, 1927.

Dinzelbacher, Peter. ed., Diccionario de la mística, translated from the German by Constantino Ruiz-Garrido. Burgos: Monte Carmelo, 2000.

Fox, Dian. "Frente a frente: Francisco de Aldana and sublimations of desire". Calíope 11.1 (2005): 65-85.

Gómez Canseco, Luis. "La contemplación según Francisco Aldana y algo más." Poesía y contemplación. Las 'Divinas nupcias' de Benito Arias Montano y su entorno literario. Huelva: Universidad de Huelva, 2007. 152-63.

Johnston, William. Silent Music. The Science of Meditation. London: Collins, 1977. 1996.

Mystical Theology. The Science of Love. London: Harper Collins,

Lara Garrido, José. ed., Francisco de Aldana. Poesías castellanas completas. Madrid: Cátedra, 1985.

Lefebvre, Alfredo. La poesía del capitán Aldana. Concepción: Universidad de Concepción, 1953.

Léon-Dufour, Xavier. Dictionary of Biblical Theology. London: Chapman, 1967.

McGinn, Bernard. "Ocean and desert as symbols of mystical absorption in the Christian tradition." Journal of Religion 74 (1994): 155-81.

Morales Borrero, Manuel. La geometría mística del alma en la literatura española del siglo de oro. Notas y puntualizaciones. Madrid: Universidad Pontificia de Salamanca-Fundación Universitaria Española, 1975.

O’Reilly, Terence. "La soledad profética de San Juan de La Cruz." Nova et Vetera 64 (2007): 273-80.

Pacho, Eulogio. ed., Diccionario de San Juan de la Cruz. Burgos: Monte Carmelo, 2000.

Parker, Alexander A. Polyphemus and Galatea. A Study in the Interpretation of a Baroque Poem, with a Verse Translation by Gilbert F. Cunningham. Edinburgh: Edinburgh UP, 1977. . The Philosophy of Love in Spanish Literature, 1480-1680. Ed. Terence O'Reilly. Edinburgh: Edinburgh UP, 1985.

Prieto, Antonio. La poesía española del siglo xvi. Madrid: Cátedra, 1998. 
Rivers, Elias L. Francisco de Aldana. El divino capitán. Badajoz: Diputación Provincial, 1955. ed. Francisco de Aldana. Poesías. Madrid: Espasa-Calpe, 1966 [1957].

Ruiz Silva, Carlos. Estudios sobre Francisco de Aldana. Valladolid: Universidad de Valladolid, 1981.

Soria Olmedo, Andrés. ed., Garcilaso Inca de la Vega. Traducción de los 'Dialogos de amor' de León Hebreo. Madrid: Biblioteca Castro, 1996.

Trueman Dicken, E.W. The Crucible of Love. A Study of the Mysticism of St Teresa of Jesus and St John of the Cross. London: Darton, Longman and Todd, 1963.

Vicente Rodríguez, José, and Federico Ruiz Salvador. eds, San Juan de la Cruz. Obras completas. Fifth edition. Madrid: Editorial de Espiritualidad, 1993.

Walters, D. Gareth. The Poetry of Francisco de Aldana. London: Tamesis, 1988. 